\title{
PEOPLE DALAM MANAJEMEN PEMASARAN SYARIAH
}

\author{
Diah Syifaul A'yuni \\ Institut Pesantren KH Abdul Chalim Mojokerto \\ Email: diah.ayuni87@gmail.com,
}

\begin{abstract}
Marketing very important for the advancement of a business, Could not be denied that marketing still play an important role in a business. With the marketing can help provide information about goods or services are offered by the company, in order to meet the needs and consumer advocacy in accordance with the market. People is all who involved in the producing the product and provide services products to consumer. A person who manufactures and markets a product also having sound judgment in the eyes of consumers. Employees is the main factors that must be considered by company in order to execute strategy company. All attitudes and the act of employees, manner of dress employees and appearance employees having influence to successful delivery of services. Talk about employees means is talk about competence (knowledge, skill, and attitude) and motivation. In support of the mission and vision of the company required employee who a reliable and of course by still uphold the syariah principle.
\end{abstract}

Keywords: Marketing Mix, People, Syariah Marketing.

\begin{abstract}
Abstrak
Pemasaran sangat berperan penting untuk kemajuan sebuah bisnis. Tak bisa dipungkiri bahwa pemasaran masih memiliki peran penting dalam sebuah bisnis. Dengan adanya pemasaran dapat membantu memberikan informasi mengenai barang atau jasa yang ditawarkan sebuah perusahaan, sehingga dapat memenuhi kebutuhan dan keinginan konsumen sesuai dengan sasaran pasar. People adalah semua orang yang terlibat dalam kegiatan memproduksi produk serta memberikan pelayanan produk kepada konsumen. Orang yang memproduksi dan memasarkan suatu produk juga memiliki penilaian dimata konsumen. Elemen dari "people" adalah pegawai perusahaan, dan konsumen. Karyawan adalah elemen utama yang harus diperhatikan oleh perusahaan dalam rangka mengeksekusi strategi perusahaan. Semua sikap dan tindakan karyawan, cara berpakaian karyawan dan penampilan karyawan memiliki pengaruh terhadap keberhasilan penyampaian jasa. Berbicara mengenai karyawan berarti adalah berbicara mengenai kompetensi (knowledge, skill, dan attitude) dan motivasi. Untuk mendukung pencapaian misi dan visi perusahaan diperlukan karyawan yang handal atau mumpuni dan tentunya dengan tetap memegang teguh prinsip syariah.
\end{abstract}

Kata kunci: Marketing Mix, People, Pemasaran Syariah.

\section{PENDAHULUAN}

Bauran Pemasaranan (marketing mix) merupakan salah satu elemen dalam strategi pemasaran jasa maupun produk. marketing mix mempunyai peranan yang sangat penting dalam kemajuan perusahaan, sehingga marketing mix harus dilakukan dengan penuh pertimbangan yang tepat. 
Menganalogikan strategi adalah hal yang sangat menarik dan juga merupakan sebuah keniscayaan untuk mempercepat pengembangan bisnis ditanah air ini. Salah satu marketng mix adalah konsep People sebagai sumber daya manusia yang beraktivitas dalam suatu pekerjaan di bidang-bidang usaha. People(Orang), bisa kita interpretasikan sebagai Sumber Daya Manusia (SDM) dari Perusahaan itu sendiri, baik secara langsung maupun tidak langsung yang akan berhubungan dengan nasabah (customer), sumber daya insani ini sendiri juga akan sangat berkorelasi dengan tingkatkepuasan para pelanggan. People dalam dunia pemasaran bisa juga dikatakan semua pihak (stakeholders) yang terlibat dalam pemasaran. Menempatkan SDI pada tempat yang sesuai dengan kapasitasnya (the right man on the right place), perlu sebuah strategi manajemen SDI yang cukup baik, karena jika strategi yang diimplementasikan keliru, maka akan berakibat fatal terhadap tingkat kepuasan pelanggan secara jangka panjang.

Elemen "People" ini meskipun hanya dalam tataran konsep semata dan belum menyentuh pembahasan secara mendetail, paling tidak bisa menjadi sebuah tawaran konsep alternatif yang sangat realistis dan bukanlah hal yang abstrak. Semuanya bisa direalisasikan guna mendukung keberhasilan percepatan perkembangan pemasaran yang berbasis Syariah agar bisa berdiri sejajar bahkan melebihi pemasaran Konvensional saat ini.

\section{DEFINISI DAN KONSEP PEOPLE ( ORANG )}

People adalah semua orang yang terlibat dalam kegiatan memproduksi produk serta memberikan pelayanan produk kepada konsumen. Orang yang memproduksi dan memasarkan suatu produk juga memiliki penilaian di mata konsumen.

Menurut (Sucipto, 2011), Orang (people) sebagai subyek, dipahami sebagai semua partisipan yangmemainkan sebagian penyajian jasa, yaitu peran selama proses dan konsumsi jasa berlangsung dalam waktu riil jasa, yang bisa mempengaruhi persepsi pembeli.

Menurut (Nirwana, 2004), people adalah orang yang memiliki andil dalam memberikan atau menunjukkan pelayanan yang diberikan kepada konsumen selama melakukan pembelian barang. 
Menurut Zeithaml and Bitner (Hurriyati, 2010), bahwa definisi orang (people) dalam bauran pemasaran jasa ialah semua pelaku yang memainkan peranan dalam penyajian jasa sehingga dapat mempengaruhi persepsi pembeli. Elemen-elemen dari "people" adalah pegawai perusahaan, konsumen dan konsumen lain dalam lingkungan jasa. Semua sikap dan tindakan karyawan bahkan cara berpakaian karyawan dan penampilan karyawan mempunyai pengaruh terhadap persepsi konsumen atau keberhasilan penyampaian jasa (service encounter).

Robert J. Eaton, CEO Chrysler Corporation, Amerika Serikat, pernah mengatakan: "The only we can beat the competition is with people". Pernyataan Eaton ini seakan-akan hendak menegaskan bahwa ditengah-tengah pesatnya kecanggihan teknologi, ternyata peran SDM dalam menentukan keberhasilan perusahaan tidak bisa diabaikan. Ibarat pepatah, SDM merupakan sumber keunggulan daya saing yang tak lekang oleh panas, tak lapuk oleh hujan. Hal ini berbeda dengan teknologi produk dan proses produksi yang dinilai makin berkurang peran pentingnya sebagai sumber keunggulan daya saing.

Dalam pemasaran jasa, kesuksesannya juga sangat bergantung pada SDM yang dimiliki. Apalagi dalam jasa, terjadi kontak antara SDM dengan konsumen secara langsung. Perusahaan juga harus mengantisipasi segala kemungkinan terjadinya permasalahan dalam pengelolaan SDM mulai dari tahap seleksi hingga proses manajemen SDM yang lebih kompleks.

Tingkat perhatian dan penekanan pada peran SDM dalam jasa adalah sangat penting, apalagi pada era globalisasi saat ini dimana tidak akan ada batas mobilitas sumber daya termasuk SDM.

Lupiyoadi, menyatakan bahwa dalam hubungannya dengan pemasaran jasa, maka people berfungsi sebagai service provider sangat mempengaruhi kualitas jasa yang diberikan. Keputusan dalam people ini berarti sehubungan dengan seleksi, training, motivasi, dan manajemen sumber daya insani. Pentingnya people dalam pemasaran jasa berkaitan erat dengan internal marketing yaitu interaksi atau hubungan antara setiap karyawan dan departemen dalam suatu perusahaan yang dalam hal ini dapat diposisikan sebagai internal customer dan internal supplier. Tujuan dari adanya hubungan tersebut 
adalah untuk mendorong people dalam kinerja untuk memberikan kepuasan kepada konsumen (Lupiyoadi, 2001).

Menurut Lupiyoadi, ada 4 (empat) kriteria peranan dan pengaruh dari aspek people yang mempengaruhi konsumen, yaitu:

1. Contactors, people di sini berinteraksi langsung dengan konsumen dalam frekuensi yang cukup sering dan sangat mempengaruhi keputusan konsumen untuk membeli.

2. Modifier, mereka tidak secara langsung mempengaruhi konsumen tetapi cukup sering berhubungan dengan konsumen, misalnya: resepsionis.

3. Influencers, tugasnya antara lain mencakup pengadaan riset dan pengembangan, peran SDM ini lebih terfokus pada implementasi dari strategi pemasaran perusahaan. Seorang Influencers harus memiliki potensi kemampuan untuk menarik konsumen melalui hasil yang diperolehnya. Keberhasilan dicapai dengan standar keinginan konsumen. Influencers juga diberikan kesempatan untuk berhubungan dengan konsumen agar hasilnya lebih baik (R\&D, periset pasar).

4. Isolateds, people di sini tidak secara langsung ikut serta dalam marketing mix dan juga tidak sering bertemu dengan konsumen. Misalnya, karyawan bagian administrasi penjualan, SDI, dan data processing.

Dalam aplikasi manajemen organisasi perusahaan hakikatnya adalah juga amal perbuatan SDM organisasi perusahaan yang bersangkutan. Dalam konteks tersebut, Islam menggariskan hakikat amal perbuatan manusia harus berorientasi pada pencapaian ridha Allah. Hal ini seperti dinyatakan oleh Imam Fudhail bin Iyadh, dalam menafsirkan surat Al-Mulk ayat 2:

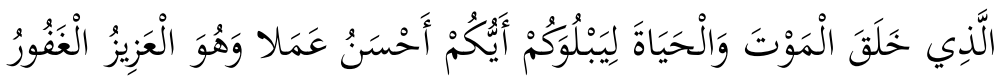

"Dia yang menciptakan kematian dan kehidupan untuk menguji kamu siapa yang paling baik amalnya Dialah Maha Perkasa dan Maha Pengampun.” (QS. A-Mulk: 2)

Ayat ini mensyaratkan dipenuhinya dua syarat sekaligus, yaitu niat yang ikhlas dan cara yang harus sesuai dengan syariat Islam. Bila perbuatan manusia memenuhi dua syarat itu sekaligus, maka amal itu tergolong baik (ahsanul ama), yaitu amal terbaik di sisi Allah. Dengan demikian, keberadaan manajemen organisasi harus dipandang pula 
sebagai suatu sarana untuk memudahkan implementasi Islam dalam kegiatan organisasi tersebut.

Manajemen marketing syariah adalah sebagai suatu ilmu memilih pasar sasaran dan mendapatkan, menjaga, dan menumbuhkan pelanggan dengan menciptakan, menyerahkan dan mengkomunikasikan nilai yang unggul kepada pelanggan dengan berorientasi pada ketentuan-ketentuan syariah (Hafidhuddin \& Tanjung, 2003).

Semua karyawan yang berhubungan dengan konsumen dapat disebut sebagai tenaga penjual. Dengan kata lain, dalam pengertian yang luas, pemasaran merupakan pekerjaan semua personel organisasi jasa. Oleh karena itu penting kiranya semua perilaku karyawan jasa harus diorientasikan kepada konsumen. Itu berarti organisasi jasa harus merekrut dan mempertahankan karyawan yang mempunyai skill, sikap, komitmen, dan kemampuan dalam membina hubungan baik dengan konsumen.

Menurut teori tentang "people", orang adalah elemen esensial yang penting dalam produksi dan penyelenggaraan pelayanan yang dapat menjadi nilai tambah dan lebih kompetitif. Dalam pemasaran jasa People atau karyawan diharapkan mempunyai karakter responsiveness, assurance, emphaty yaitu mempunyai kemampuan cepat tanggap menyelesaikan keluhan customer, memberikan informasi yang jelasdan mudah dimengerti, tindakan cepat saat customer membutuhkan. Juga petugas memiliki ketrampilan, pelayanan yang sopan.

People dalam menjalankan segala aktivitas perusahaan, dan merupakan faktor yang memegang peranan penting bagi semua organisasi.Oleh perusahaan barang dan jasa unsur people ini bukan hanya memegang peranan penting dalam bidang produksi atau operasional saja, tetapi juga dalam melakukan hubungan kontak langsung dengan konsumen. Perilaku orang-orang yang terlibat langsung ini sangat penting dalam mempengaruhi mutu barang dan jasa yang ditawarkan dan image perusahaan yang bersangkutan, elemen people ini memiliki 2 aspek, yaitu:

\section{Service people}

Untuk organisasi perusahaan barang dan jasa, servicepeople biasanya memegang jabatan ganda, yaitu mengadakan jasa dan menjual jasa tersebut.melalui pelayanan yang baik, cepat, ramah, teliti dan kesetiaan pelanggan terhadap perusahaan yang akhirnya akan meningkatkan nama baik perusahaan. 


\section{Customer service}

Customer service pada pemasaran produk pada dasarnya dilakukan oleh pemilik usaha maupun pegawai yang bekerja melayani pelanggan. Tujuan pelayanan yang diberikan agar pelanggan merasa puas dan mendapatkan produk yang diinginkan tanpa keluhan apapun.Tercapainya kepuasan sepenuhnya (Total Customer Satisfaction) merupakan tujuan akhir konsep suatu strategi pemasaran.

Dengan melihat berbagai peran penting SDM dalam perusahaan tentunya diharapkan manajemen tidak lagi memandang sumber daya ini hanya dengan sebelah mata. Kelalaian dalam perencanaan, pengembangan, pelaksanaan serta pengawasan terhadap SDM yang dimiliki akan merugikan perusahaan. Peran penting dalam pemasaran jasa dapat dijelaskan dalam aspek internal marketing dan customer service.

Menyadari bahwa manajemen SDM merupakan suatu kegiatan menyeluruh dari perusahaan yang melibatkan hubungan antara organisasi dengan para karyawan yang menjadi kekayaan utama dalam pemasaran jasa, maka diperlukan suatu komitmen yang tinggi dari seluruh elemen yang terlibat di dalamnya. Dewasa ini mulai berkembang suatu pandangan bahwa untuk memasarkan jasa dengan baik kepada konsumen di luar perusahaan, usahakan untuk memenuhi kebutuhan internal perusahaan terlebih dahulu recruitment SDM yang bermutu. Untuk dapat memberikan kualitas terbaik pada external marketing, maka harus dipastikan setiap karyawan mendapatkan kepuasan kerja yang optimal.

Pandangan yang sama terhadap misi, strategi dan tujuan perusahaan merupakan elemen yang penting untuk menciptakan komitmen yang tinggi pada setiap karyawan yang pada akhirnya memotivasi karyawan untuk bekerja optimal. Untuk dapat meraih kesuksesan dalam internal marketing, perusahaan jasa perlu menekankan pada pentingnya komunikasi, keterbukaan, tanggung jawab dan integritas yang tinggi terhadap pencapaian tujuan. Internal marketing merupakan langkah awal untuk menciptakan motivasi yang tinggi baik bagi karyawan maupun konsumen sebagai pengguna jasa.

Dalam menciptakan suatu kerjasama jangka panjang antara manajemen, karyawan dan konsumen, konsep internal marketing ini memberikan suatu pandangan bahwa internal market of employees akan memberikan pengaruh yang cukup signifikan 
bagi perusahaan maupun bagi kosumen sehingga internal marketing penting untuk diperhatikan sebagai upaya yang besifat jangka panjang. Proses manajemen yang penting dalam hal ini menurut Gronroos (1990) adalah:

\section{Attitude Management}

Meliputi sikap dan motivasi karyawan dalam pelaksanaan kegiatan perusahaan. Pihak manajemen perlu bersifat proaktif terutama dalam perencanaan dan pengawasan kegiatan karyawannya.

\section{Communication Management}

Merupakan proses manajemen dalam menyampaikan setiap informasi yang bertujuan untuk memberikan petunjuk kerja dan memberikan kesempatan pula pada para karyawan untuk menyampaikan segala permasalahan yang dihadapi sehingga dapat terjadi komunikasi dua arah dan terjalin suasana keterbukaan.

Pada kenyataannya, seringkali hal yang pertama lebih diutamakan dan merupakan proses yang berkelanjutan sementara komunikasi hanya dilakukan sewaktuwaktu saja. Untuk mencapai kesuksesan, sebaiknya kedua proses tersebut harus dijalankan secara seimbang. Merupakan program yang ditujukan bagi SDM perusahaan berupa pemberian informasi pengetahuan dasar mengenai strategi kerja, sikap, kemampuan, baik berkomunikasi maupun pemasaran jasa serta memahami konsumen, hal ini bisa dijelaskan antara lain:

a. Manajemen komunikasi supportand internal interactive communication; merupakan sarana kerjasama yang efektif dari kalangan manajemen perusahaan kepada SDM pelaksana dan juga membuka komunikasi dua arah dari karyawan kepada atasan. Informasi meliputi masalah kerja atau keputusan-keputusan penting lainnya dalam perusahaan.

b. Personnel adminstration tools and human resources management; Manajemen perlu mempersiapkan program perencanaan SDM yang tepat dan efektif agar dalam pelaksanaan sesuai strategi yang telah ditetapkan perusahaan.

c. Developing a service culture; Manajemen perusahaan harus dapat menciptakan suatu pola yang sama untuk setiap SDM agar kinerjanya memuaskan konsumen. Untuk perusahaan jasa, internal marketing memberikan banyak manfaat dalam mencapai kesuksesan pemasaran karena 
lebih bersifat integratif dan merupakan proses yang berkelanjutan. Manfaat tersebut antara lain:

1) Sarana efektif untuk mengembangkan keunggulan-keunggulan kompetitif yang dimiliki perusahaan karena internal marketing memberikan suasana keterbukaan, sehingga memungkinkan penggalian informasi terutama mengenai potensi SDM.

2) Mengurangi adanya konflik, karena terencananya setiap program dan partisipasi sangat ditekankan dalam pengambilan keputusan.

3) Memfasilitasi adanya inovasi, karena internal marketing merupakan proses berkelanjutan dan memotivasi karyawan untuk berpikir kreatif.

3. Membangun customer service

Perbedaan utama antara perusahaan penghasil produk berupa barang dengan perusahaan penghasil jasa adalah pada pemasarannya, dimana jasa lebih dituntut memberikan kualitas yang optimal dari customer service. Konsumen dapat memiliki penilaian yang sangat subyektif terhadap suatu jasa karena mereka merasakan standar kualitas pelayanan yang diberikan berpengaruh pada kepuasan yang hendak diraih.

Bagi perusahaan jasa tentu cukup sulit untuk mengadakan standar pelayanan yang sama dimata konsumen. Hal tersebut menuntut kecermatan dalam pengelolaan SDM yang dimiliki agar kinerjanya optimum dan memuaskan konsumen. Ditengah kondisi persaingan di sektor jasa yang semakin meningkat, perusahaan hendaknya terus meningkatkan customer service.

Customer service meliputi berbagai aktivitas di seluruh area bisnis yang berusaha mengkombinasikan antara penjualan jasa untuk memenuhi kepuasan konsumen mulai dari pemesanan, pemrosesan, hingga pemberian hasil jasa melalui komunikasi untuk mempererat kerja sama dengan konsumen. Tentu saja tujuannya adalah memperoleh keunt ungan. customer service bukan sekedar maksud melayani namun merupakan upaya untuk membangun suatu kerja sama jangka pajang dengan prinsip saling menguntungkan. Proses ini sudah dimulai sebelum terjadi transaksi hingga tahap evaluasi setelah transaksi. Customer service yang baik adalah bagaimana mengerti keinginan konsumen dan senantiasa memberikan nilai tambah di mata konsumen. Untuk mencapai kinerja yang tinggi dalam customer service, manajemen perusahaan jasa juga 
harus menyiapkan SDM melalui training tentang bagaimana dengan strategi dan operasi perusahaan yang telah ditetapkan. Seluruh komponen SDM adalah customer service yang memiliki tanggung jawab terfokus pada tugas menjalankan pemasaran bukan hanya di areanya saja. Pada umumnya customer service hanya terpusat pada satu bagian, yang sering menimbulkan ketidakpuasan konsumen karena untuk mendapatkan pelayanan harus melalui birokrasi berbelit-belit. Manajemen perusahaan hendaknya secara jelas mendelegasikan tugas ke seluruh bagian dengan orientasi pada konsumen, baik untuk SDM yang terlibat pada front office maupun back office.

Pandangan integral tentang customer service dari setiap SDM perusahaan hendaknya selalu ditingkatkan. Kunci kesuksesannya adalah pada sistem pelayanan (reservation) yang diberikan kepada konsumen serta memperhatikan perannya dalam customer service.

\section{Desain customer service}

Mendapatkan hasil kerja yang baik dalam pemberian jasa, tentu harus diikuti dengan adanya desain dan strategi yang tepat dari perusahaan jasa bersangkutan. Beberapa langkah penting dalam mendesain customer service adalah:

a. Identifying a service mission; Sebagai tahap awal tentu harus ditetapkan misi perusahaan agar dapat menciptakan suatu komitmen dan falsafah kerja sama untuk mencapai misi tersebut.

b. Setting customer service objective; Tujuan pelayanan merupakan hal penting lainnya yang harus ditetapkan perusahaan. Hal ini bermanfaat untuk menentukan elemen mana yang diutamakan untuk mencapai hasil yang optimal. Tujuan pelayanan ini mencakup aktivitas sebelum transaksi, saat berlangsung transaksi dan setelah aktivitas transaksi. Selain itu perusahaan dapat memperhatikan value apa yang diinginkan konsumen, suatu jasa, namun segmentasi dapat membantu perusahaan dalam menetapkan standar pelayanan yang dapat diberikan kepada setiap segmen pasarnya. Strategi customer service yang ditetapkan harus mencakup identifikasi dari segmen konsumen, jasa dan konsumen yang paling penting serta bagaimana metode pemberian jasanya agar dapat bersaing di pasaran sekaligus merupakan keunggulan tersendiri bagi perusahaan. 
c. Implementation; Dalam implementasinya customer servicemerupakan suatu kesatuan dengan marketing mix lainnya yang dimiliki perusahaan. Perusahaan jasa hendaknya senantiasa berusaha mengadaptasi setiap perubahan lingkungan yang terjadi terutama yang berkaitan dengan perilaku konsumen. Hal ini penting untuk menghasilkan desain customer serviceyang tepat dan efektif. Kemampuan manajemen untuk mengkomunikasikan strategi kepada SDM pelaksana akan sangat menentukan keberhasilan kualitas customer service yang baik.

Hal penting lainnya yang perlu mendapat perhatian dari operasi jasa adalah bagaimana pola dan proses manajemen yang digunakan organisasi yang efektif, manajemen hendaknya mengupayakan pemberdayaan SDM melalui:

\section{Recruit the Right Employees}

Melakukan rekruitmen pegawai sesuai dengan kualifikasi perusahaan agar pemasaran jasa berlangsung baik. Kemampuan yang perlu dicermati antara lain adalah keahlian teknik dan karakteristik personal yang dimiliki. Penilaian ini tergantung pada tuntutan kerja yang ada.

\section{Train Employees Properly}

Walaupun SDM yang ada adalah hasil seleksi bukan berarti tidak memerlukan pelatihan. Pelatihan tetap diberikan sebagai bekal untuk menghadapi apabila konsumennya memiliki informasi yang jelas dan lengkap mengenai jasa yang ditawarkan perusahaan. Konsumen dan penyedia jasa akan dapat berinteraksi sehingga tidak ada unsur ketertutupan dalam kerja sama.

\section{Educate All Employees}

Internal marketing juga menjadi fokus dalam menciptakan manajemen operasi yang baik. Apabila karyawan memiliki sikap dan kemampuan pelayanan yang baik maka segala permasalahan akan dapat diatasi.

4. Be Effective First, Nice Second

Pemberian/pelayanan jasa adalah pertama efisiensi baru kemudian sikap ramah.

\section{Standardize Response Sistem}

Manajemen perlu menyiapkan standar untuk menangani kesulitan dan kritik yang disampaikan konsumen. 


\section{Be Proactive}

Perusahaan harus jeli melihat setiap peluang yang ada dan menentukan strategi operasi yang tepat untuk mencapai sasaran.

\section{Evaluate Performance Regularly}

Evaluasi kinerja secara rutin akan sangat berguna bagi manajemen untuk mengetahui kinerja perusahaan dan memberikan masukan tentang hal-hal mana yang perlu diperbaiki. Perusahaan perlu mengambil tindakan koreksi untuk setiap operasi yang gagal atau kurang dari standar yang ditetapkan. Tindakan koreksi yang mungkin diambil antara lain adalah melatih kembali SDM yang dimiliki, mengadakan rotasi kerja untuk meningkatkan motivasi atau mengganti SDM perusahaan yang sudah tidak memiliki kesesuaian dengan strategi perusahaan.

Implementasi dari seluruh aspek yang terkait dengan SDM perusahaan jasa ini menuntut adanya suatu komitmen, cara pandang dan pelaksanaan peran. Konsumen dalam mempersepsikan value dari kualitas, sering ditentukan oleh customer value dari perusahaan. Bahkan customer service telah menjadi senjata utama dalam memenangkan persaingan. Industri asuransi, bank, perusahaan penerbangan, bahkan manufaktur kesulitan membedakan output perusahaan mereka dengan pesaingnya kecuali melalui customer service. Siapapun dapat meniru penawaran jasa yang disajikan. Misalnya: Bank Syariah menawarkan keamanan, kemudahan, tingkat bagi hasil yang menarik,dll, yang semua hampir dapat dipenuhi oleh semua bank. Perusahaan asuransi syariah menawarkan keamanan dan jaminan dan lainnya, yang bisa dipenuhi oleh setiap perusahaan asuransi yang ada.

\section{KONSEP PEOPLEDALAM ISLAM}

Sebagaimana diuraikan sebelumnya bahwa people sebagai penyedia jasa dalam sebuah perusahaan, dimana seorang karyawan dituntut untuk dapat berlaku profesional dalam memberikan layanan terbaik kepada pelanggan, bertutur kata yang ramah, berpakaian rapi, sopan dan santun. Hal ini selaras dengan ajaran Islam bahwasanya manusia diperintahkan untuk dapat berperilaku lemah lembut terhadap sesamanya. Sebagaimana dalam firman Allah SWTyang artinya: 
Maka disebabkan rahmat dari Allah-lah kamu Berlaku lemah lembut terhadap mereka. Sekiranya kamu bersikap keras lagi berhati kasar, tentulah mereka menjauhkan diri dari sekelilingmu... (QS. Ali Imran: 159)

Demikian pula berkenaan dengan sikap profesionalisme dalam melakukan suatu pekerjaan, Rasulullah SAW. menekankan pentingnya sikap profesional. Beliau mengatakan: “Jika menempatkan seseorang bukan pada pekerjaan yang dia kuasai, maka bersiaplah untuk mengalami kehancuran”. Hal ini sesuai dengan firman Allah SWT yang artinya:

Katakanlah: "Tiap-tiap orang berbuat menurut keadaannya masing-masing". Maka Tuhanmu lebih mengetahui siapa yang lebih benar jalanNya. (QS. Al-Isra: 84)

Sesungguhnya Allah SWT mengetahui kemampuan manusia untuk melaksanakan tanggung jawabnya. Atas dasar inilah yang menjadi motivasi bagi muslim untuk menjaga kualitas dirinya dalam meningkatkan kualitas produk dan pelayanan yang dikelolanya. Sehingga individu muslim yang dapat memahami dan melaksanakan tanggung jawabnya secara baik, maka ia akan memperbaiki kualitas pekerjaannya.

\section{KESIMPULAN}

People adalah semua orang yang terlibat dalam kegiatan memproduksi produk serta memberikan pelayanan produk kepada konsumen. Orang yang memproduksi dan memasarkan suatu produk juga memiliki penilaian di mata konsumen.

People sebagai penyedia jasa dalam sebuah perusahaan, dimana seorang karyawan dituntut untuk dapat berlaku profesional dalam memberikan layanan terbaik kepada pelanggan, bertutur kata yang ramah, berpakaian rapi, sopan dan sant un. Hal ini selaras dengan ajaran Islam bahwasanya manusia diperintahkan untuk dapat berperilaku lemah lembut terhadap sesamanya. 
AL-'ADALAH: Jurnal Syariah dan Hukum Islam

e-ISSN: 2503-1473

Hal. 191-203

Vol. 3, No. 3, November 2018

\section{DAFTAR PUSTAKA}

Hafidhuddin, D., \& Tanjung, H. (2003). Manajemen Syariah dalam Praktek. Jakarta: Gema Insani.

Hurriyati, R. (2010). Bauran Pemasaran dan Loyalitas Konsumen. Bandung: Alfabeta.

Lupiyoadi, R. (2001). Manajemen Pemasaran Jasa. Jakarta: PT. Salemba Empat.

Nirwana. (2004). Prinsip-prinsip Pemasaran Jasa. Malang: Dioma.

Sucipto, A. (2011). Studi Kelayakan Bisnis. Malang: UIN MALIKI PRESS. 